\title{
STUDY ON THE COMPOSITION AND PROPERTIES OF PYROLYSIS PYROCONDENSATE OF USED TIRES
}

\author{
Ksenia Hrynyshyn ${ }^{1}$, Volodymyr Skorokhoda1, Taras Chervinskyy ${ }^{1,}$
}

https://doi.org/10.23939/chcht16.01.159

\begin{abstract}
A low-temperature pyrolysis, the target product of which is pyrocondensate, is one of the options for the recycling used tires. The fractional composition and properties of pyrocondensate of rubber waste pyrolysis obtained at an industrial plant have been studied. The pyrocondensate was separated into gasoline, diesel fraction and residue. The composition and properties of obtained products were determined using X-ray fluorescence analysis and IR spectroscopic studies.
\end{abstract}

Keywords: used tires, recycling, pyrolysis, pyrocondensate, X-ray fluorescence analysis, IR spectroscopy.

\section{Introduction}

Modern requirements for hydrocarbons-based products demand the expansion of their production. ${ }^{1}$ In recent years, the by-products of monomers production ${ }^{2-4}$ and coal coking ${ }^{5}$ have been used as raw materials for the production of polymers (resins). The main liquid byproducts obtained during the hydrocarbons pyrolysis to ethylene and propylene, are pyrocondensate and heavy resin, the yield of which varies between 25-30\%. Pyrocondensate is usually divided into $\mathrm{C}_{5}$, benzenetoluene-xylene (BTX) and $\mathrm{C}_{8}-\mathrm{C}_{9}$ fractions. ${ }^{2}$ The $\mathrm{C}_{5}$ fraction contains mainly diene hydrocarbons, in particular isoprene, cyclodiene and piperylenes. The content of such products, depending on the technological parameters of the process, can be from 50 to $75 \%$. ${ }^{23}$ The BTX fraction is used to produce individual aromatic hydrocarbons (benzene, toluene and xylenes). The $\mathrm{C}_{8}-\mathrm{C}_{9}$ fraction, which consists of $5-60 \%$ of unsaturated compounds, is used to obtain the socalled petroleum polymer resins (PPR). ${ }^{2}$ The main unsaturated compounds in this fraction are: styrene (17$27 \%), \quad \alpha$-methylstyrene $(2-5 \%), \quad$ vinyltoluene and dicyclopentadiene (6-19\%), indene (8-20\%) and others. ${ }^{2-4}$

In order to extend the application area of PPR, especially for the creation of various composite materials,

\footnotetext{
${ }^{1}$ Lviv Polytechnic National University,

12 Bandery St., Lviv 79013, Ukraine

chervinskijt@gmail.com

(C) Hrynyshyn, K.; Skorokhoda, V.; Chervinskyy, T., 2022
}

the researchers of Lviv Polytechnic National University have conducted studies on improving the PPR functionality ${ }^{6-9}$ For this purpose, PPR with epoxy, ${ }^{6,10-14}$ carboxy, ${ }^{75-18}$ and hydroxy ${ }^{8,19}$ groups were synthesized.

Another interesting approach to the creation of new polymers is the use of coal coking by-products. ${ }^{4}$ These byproducts, in particular the light fraction, containing indene, coumarone, styrene and other hydrocarbons. This made it possible to create on its basis the indenecoumarone resins with carboxy, ${ }^{4}$ epoxy, ${ }^{20,21}$ and methacrylate ${ }^{22}$ groups. The synthesized indene-coumarone resins with functional groups are used as active additives to improve the properties of petroleum bitumen. ${ }^{21}$

Today, apart from the by-products formed in the industrial processing of carbon-containing materials, the accumulation of rubber waste is an important problem. The main type of rubber waste is used tires, which accumulate in the world during the year up to 10 million tons. ${ }^{23}$ Moist of the developed countries recycle $70-90 \%$ of such waste. ${ }^{23}$ In Ukraine, the annual increase in used tires is 250-300 thousand tons, and the level of their exploitation does not exceed $10 \%$. ${ }^{24,25}$

There are several approaches to recycle the used tires, in particular, the combustion of tires to produce thermal energy, ${ }^{26}$ the tires grinding to produce a rubber crumb, which is used as additives in construction ${ }^{27,28}$ and for improvement of petroleum bitumen properties. ${ }^{29,30}$

Thermal methods of used tires recycling are gasification and pyrolysis. The gasification process (or high-temperature pyrolysis) is carried out at the temperatures of 1073-1473 K. Under such conditions, a large number of gaseous products (which can be used as a fuel gas or a synthesis gas) and a solid residue (pyrocarbon) are formed. ${ }^{31}$

The pyrolysis of used tires and other rubber waste is carried out at a temperature of 723-773 K using batch plant. $^{32}$ A liquid product (pyrocondensate), pyrolysis gas and a solid residue (pyrocarbon) are formed. ${ }^{33}$ Pyrolysis pyrocondensate is mostly used as a furnace fuel. This method is unprofitable, taking into account the relatively low cost of this type of fuel. A detailed study on the composition and properties of pyrocondensate would make it possible to propose new directions of its use, in 
particular, for the production of hydrocarbons, which can be attributed to gasoline and diesel fractions.

So, the aim of this work is to study the composition and properties of pyrocondensate obtained via pyrolysis of used tires and fractions extracted from it, as well as to find the most rational way of their usage.

\section{Experimental}

\subsection{Materials}

The starting material was pyrocondensate obtained from EcoPromGroup JSC (Lviv region, Ukraine). Pyrocondensate is a black liquid with a characteristic odor. Its characteristics is represented in Table 1.

Table 1. Characteristics of pyrocondensate

\begin{tabular}{|l|c|}
\hline \multicolumn{1}{|c|}{ Index } & Value \\
\hline Density, $\mathrm{kg} / \mathrm{m}^{3}$ & 927 \\
\hline Refractive index & 1.4889 \\
\hline Sulfur content, $\mathrm{wt}^{\%} \mathrm{O}$ & 1.59 \\
\hline Iodine value, $\mathrm{gI}_{2} / 100 \mathrm{~g}$ & 67.8 \\
\hline Pour point, $\mathrm{K}$ & 249 \\
\hline Flash point, $\mathrm{K}$ & \\
open cup & 341 \\
closed cup & 314 \\
\hline
\end{tabular}

\subsection{Methods}

Frationation of pyrocondensate. The pyrocondensate was fractionated into narrow fractions at the laboratory setup under atmospheric pressure according to the method described by Topilnytskyy et $a .^{34}$ and Rybak. $^{35}$

Analyzes. All analyzes were performed according to generally accepted standard methods. ${ }^{34-36}$

$\mathrm{X}$-ray fluorescence spectral analysis was performed to determine the elemental composition of liquid and solid pyrolysis products using a precision analyzer Elvax Light SDD. IR spectroscopic studies of narrow fractions of pyrocondensate were performed in a zinc selenide cuvette of $0.1036 \mathrm{~mm}$ thick of Spectrum Two FT-IR spectrometer (Perkin Elmer). The Spectrum v.10.03.06 software was used to calculate the results.

\section{Results and Discussion}

In accordance with the characteristics presented in Table 1 it is obvious that sulfur content and flash point of pyrocondensate do not meet the requirements for furnace or boiler fuel. A characteristic feature is also the absence of a light gasoline fraction (boiling point is $357 \mathrm{~K}$, Fig. 1). A sufficiently high iodine value indicates the presence of unsaturated hydrocarbons, which are undesirable components in all petroleum fuels (Table 1).

When fractionating pyrocondensate according to the method described in subsection 2.2, we obtained the fraction IBP-473 K, the fraction $473-573 \mathrm{~K}$ and the residue, the characteristics of which are given in Table 2.

The fraction IBP- $473 \mathrm{~K}$ is a clear dark brown liquid with a characteristic odor. This fraction was found to be characterized by a weighted fractional composition, very low saturated vapor pressure and relatively high density, as for gasoline. It contains $0.70 \mathrm{wt} \%$ of sulfur and unsaturated hydrocarbons (Table 2) and corresponds to the gasoline fraction.

The fraction $473-573 \mathrm{~K}$ is a cloudy dark brown liquid with a characteristic odor. The formation of a precipitate is observed. This fraction of pyrocondensate is characterized by a very high sulfur content $(1.75 \mathrm{wt} \%$, Table 2$)$. The cloud point and pour point of this fraction meets the requirements for summer diesel fuels. The same as for pyrocondensate and the gasoline fraction extracted from it, the diesel fraction contains unsaturated hydrocarbons.

The residue is a product that is visual reminiscent of plastic lubricant. It contains a lot of sulfur and unsaturated hydrocarbons and is characterized by a pour point of $302 \mathrm{~K}$ (Table 2).

The content of individual chemical elements in the pyrocondensate and narrow fractions extracted from it was determined by X-ray fluorescence spectral analysis (Table 3).

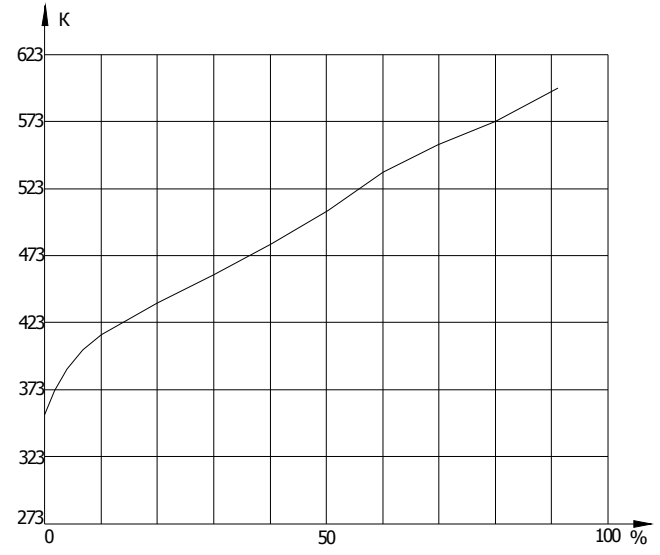

Fig. 1. Temperature distillation chart of pyrocondensate of used tires pyrolysis

It was found that pyrocondensate and its fractions contain traces of heavy metals $(\mathrm{V}, \mathrm{Ni})$ characteristic of petroleum fractions and residues. Instead, $\mathrm{Ca}, \mathrm{Fe}, \mathrm{Zn}$ were detected. Moreover, $\mathrm{Fe}$ and $\mathrm{Zn}$ are concentrated mainly in the residue, and $\mathrm{Ca}$ - in the gasoline fraction. However, the content of these metals is insignificant and cannot pose a threat in the processing of individual fractions at the classic refining units. 
Table 2. The composition and characteristics of the obtained products

\begin{tabular}{|c|c|c|c|}
\hline Index & Fraction IBP-473 K & Fraction $473-573 \mathrm{~K}$ & Residue \\
\hline Yield relative to pyrocondensate, $\mathrm{wt} \%$ & 36.6 & 43.4 & 20.0 \\
\hline Density, $\mathrm{kg} / \mathrm{m}^{3}$ & 837 & 920 & 978 \\
\hline Refractive index & 1.4644 & 1.5135 & 1.5328 \\
\hline Saturated vapor pressure, $\mathrm{kPa}$ & 5.2 & & \\
\hline Fractional composition, K: & & & \\
\hline IBP & 353 & 468 & \\
\hline $10 \%$ distilled at & 383 & 488 & \\
\hline $50 \%$ distilled at & 416 & 537 & \\
\hline $90 \%$ distilled at & 458 & 567 & \\
\hline EBP & 478 & 577 & \\
\hline Sulfur content, wt $\%$ & 0.70 & 1.75 & 1.70 \\
\hline Iodine value, $\mathrm{gI}_{2} / 100 \mathrm{~g}$ & 49.5 & 74.8 & 68.7 \\
\hline Cloud point, $\mathrm{K}$ & & 263 & \\
\hline Pour point, $\mathrm{K}$ & & 254 & 302 \\
\hline Flash point, K & & & \\
\hline open cup & & & 388 \\
\hline $\begin{array}{c}\text { closed cup } \\
\text { Ash content, } \%\end{array}$ & & $\begin{array}{c}550 \\
0.865\end{array}$ & \\
\hline $\begin{array}{l}\text { Penetration (cone), } 0 . \mathrm{mmMM} \\
\end{array}$ & & & 246 \\
\hline
\end{tabular}

Table 3. The content of individual chemical elements in the pyrocondensate and obtained products

\begin{tabular}{|c|c|c|c|c|}
\hline \multirow{2}{*}{ Element } & \multicolumn{3}{|c|}{ Element content, ppm } \\
\cline { 2 - 5 } & \multirow{2}{*}{ Pyrocondensate } & Fraction IBP-473 K & Fraction 473-573 K & \multirow{2}{*}{ Residue } \\
\hline $\mathrm{Ca}$ & 17.6 & 31.9 & 13.5 & 16.4 \\
\hline $\mathrm{V}$ & $<0.1$ & $<0.1$ & $<0.1$ & $<0.1$ \\
\hline $\mathrm{Cr}$ & $<1.7$ & $<1.8$ & $<1.7$ & $<2.1$ \\
\hline $\mathrm{Mn}$ & $<0.1$ & $<0.1$ & 6.1 & 64.0 \\
\hline $\mathrm{Fe}$ & 22.1 & $<0.8$ & $<0.4$ & 1.3 \\
\hline $\mathrm{Ni}$ & $<0.4$ & $<0.4$ & 22.1 & 74.1 \\
\hline $\mathrm{Cu}$ & 28.6 & 12.6 & 32.2 & $<8.2$ \\
\hline $\mathrm{Zn}$ & 21.9 & $<0.3$ & $<0.1$ & $<0.1$ \\
\hline $\mathrm{Ba}$ & $<0.1$ & $<0.1$ & 4.9 & 4.0 \\
\hline $\mathrm{Mo}$ & 4.0 & 3.7 & $<1.0$ & 1.6 \\
\hline $\mathrm{Pb}$ & $<1.0$ & $<1.0$ & & \\
\hline
\end{tabular}

The largest amount of sulfur and unsaturated hydrocarbons was found in the diesel fraction of pyrocondensate (Table 2). The content of these substances in the gasoline fraction and the residue is slightly lower.

To determine more accurately the hydrocarbon composition of pyrocondensate, the IR spectroscopy was used. The results are shown in Fig. 2.

It is obvious that the pyrocondensate contains paraffin-naphthenic hydrocarbons (absorption bands at 2922, 2853, 1453 and $1375 \mathrm{~cm}^{-1}$ ). The presence of monocyclic aromatic hydrocarbons is confirmed by absorption bands at 875 and $1610-1603 \mathrm{~cm}^{-1}$; the polycyclic hydrocarbons are characterized by the bands at $900-695 \mathrm{~cm}^{-1}$. Olefin hydrocarbons can be identified by absorption bands in the range of $1680-1603 \mathrm{~cm}^{-1}$. The presence of oxygen-containing compounds (ethers, alcohols, acids) is confirmed by absorption bands in the range of $1150-1032 \mathrm{~cm}^{-1}$.

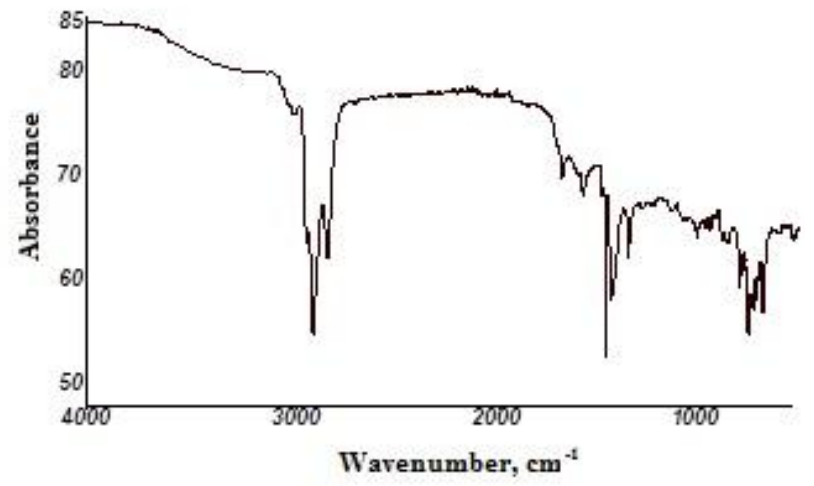

Fig. 2. IR spectrum of pyrocondensate after used tires pyrolysis

The determined quality indices will become the further basis for the development of a variant of 
pyrocondensate rational use, namely the production of commercial motor fuels.

Preliminary analysis of the obtained results showed that the narrow fractions extracted from pyrocondensate can not be used as components of commercial petroleum fuels. These fractions must be pre-processed separately or in a mixture with the appropriate petroleum fractions, but the choice of their application requires further research.

\section{Conclusions}

The main properties of pyrocondensate of used tires pyrolysis were studied. It was found that pyrocondensate contains a significant amount of unsaturated hydrocarbons (iodine value is $67.8 \mathrm{gI}_{2} / 100 \mathrm{~g}$ ) and sulfur (1.59 wt \%).

The composition and properties of narrow fractions extracted from pyrocondensate were investigated. The fraction IBP- $473 \mathrm{~K}$ corresponds to the gasoline fraction, has a weighted fractional composition (initial boiling point is $353 \mathrm{~K}$ ) and sulfur content of $0.70 \mathrm{wt} \%$. The fraction $473-573 \mathrm{~K}$ corresponds to the diesel fraction and contains the largest amount of unsaturated hydrocarbons (iodine value is $74.8 \mathrm{gI}_{2} / 100 \mathrm{~g}$ ) and sulfur (1.75 wt\%).

Virtually no heavy metals such as $\mathrm{V}$ or $\mathrm{Ni}$, characteristic for petroleum fractions and residues, were found in pyrocondensate and its fractions. Instead, $\mathrm{Ca}, \mathrm{Fe}$ and $\mathrm{Zn}$ were detected. Moreover, $\mathrm{Fe}$ and $\mathrm{Zn}$ are concentrated mainly in the residue of pyrocondensate fractionation, and $\mathrm{Ca}$ is observed in the gasoline fraction.

It was established that pyrocondensate and narrow fractions extracted from it cannot be used as marketable products without further processing.

\section{References}

[1] Hetmanchuk, Yu.P.; Bratychak, M.M. Khimiya ta Tekhnolohiya Polimeriv. Beskyd BiT: Lviv 2006.

[2] Bratychak, M.M.; Grynyshyn, O.B.; Prysyazhnyy, YU.V.; Pushak, A.P. Naftopolimerni Smoly iz Funktsiynymy Grupamy. Syntez, Vlastyvosti, Zastosuvannya. Vydavnytsvo Lvivskoyi politekhniky: Lviv, 2016.

[3] Bratychak, M.; Gagin, M.; Shyshchak, O.; Waclawek, W. Obtaining of Petroleum Resins Using Pyrolysis By-Products. 1. Hydrocarbon Pyrolysis By-Products. Ecol. Chem. Eng. S 2004, 11 (S1), 15-20.

[4] Michael Bratychak, Myroslava Gagin, Olena Shyshchak, Witold Waclawek. Obtaining of Petroleum Resins Using Pyrolysis ByProducts. 2. Method of Petroleum Resins Obtaining. Ecol. Chem. Eng. S 2004, 11 (S1), 21-26.

[5] Bratychak, M.; Astakhova, O.; Shyshchak, O.; Namiesnik, J.; Ripak, O.; Pyshyev, S. Obtaining of Coumarone-Indene Resins Based on Light Fraction of Coal Tar. 1. Coumarone-Indene Resins with Carboxygroups. Chem. Chem. Technol. 2017, 11, 509. https://doi.org/10.23939/chcht11.04.509
[6] Bratychak, M.; Brostow, W.; Grynyshyn, O.; Shyshchak, O. Synthesis and Characterization of Petroleum Resins with Epoxy Groups. Mater. Res. Innov. 2003, 7, 167-171.

https://doi.org/10.1007/s10019-003-0243-5

[7] Skibitskiy, V.; Grynyshyn, O.; Bratychak, M.; Waclawek, W. Obtaining of Petroleum Resins Using Pyrolysis By-Products. 4.

Resins with Carboxy Groups. Ecol. Chem. Eng. S 2004, 11 (S1), 4151.

[8] Bratychak, M.; Grynyshyn, O.; Shyshchak, O.; Romashko, I.; Waclawek, W. Obtaining of Petroleum Resins Using Pyrolysis ByProducts. 12. Petroleum Resins with Hydroxyl Groups. Ecol. Chem. Eng. S 2007, 14 (2), 225-234.

[9] Bratychak, M.; Shust, O.; Chervinskyy, T.; Shyshchak, O.; Waclawek, W. Obtaining of Petroleum Resins Using Pyrolysis ByProducts. 14. Petroleum Resins with Fluorine Atoms. Ecol. Chem. Eng. S 2011, 18 (1), 49-54.

[10] Gagin, M.; Bratychak, M.; Shyshchak, O. Waclawek, W. Obtaining of Petroleum Resins Using Pyrolysis By-Products. 3. Petroleum Resins with Epoxy Groups. Ecol. Chem. Eng. S 2004, 11 (S1), 27-40.

[11] Bratychak, M.; Gagin, M.; Shyshchak, O.; Waclawek, W. Obtaining of Petroleum Resins Using Pyrolysis By-Products. 5. Epoxy-Oligomeric Composites on the Basis of Petroleum Resins with Epoxy Groups. Ecol. Chem. Eng. S 2004, 11 (S1), 53-58.

[12] Chervinskyy, T.; Bratychak, M.; Gagin, M.; Waclawek, W. Obtaining of Petroleum Resins Using Pyrolysis By-Products. 6. Petroleum Resins with Epoxy Groups as Active Components of Epoxy-Polymeric Composites. Ecol. Chem. Eng. S 2004, 11 (11), 1225-1231.

[13] Bratychak, M.; Shyshchak, O.; Romashko, I.; Bratychak Mich.; Waclawek, W. Obtaining of Petroleum Resins Using Pyrolysis ByProducts. 8. Petroleum Resins with Epoxy Groups Modified with Maleic Anhydride. Ecol. Chem. Eng. S 2006, 13 (S1), 17-24. [14] Bratychak, M.; Romashko, I.; Shyshchak, O.; Bratychak. Mich.; Waclawek, W. Obtaining of Petroleum Resins Using Pyrolysis By-Products. 9. Petroleum Resins with Epoxy Groups Modified Simultaneously with Maleic Anhydride and Styrene. Ecol. Chem. Eng. S 2006, 13 (S1), 25-33.

[15] Bratychak, M.; Romashko, I., Shyshchak, O.; Bratychak, Mich.; Waclawek, W. Obtaining of Petroleum Resins Using Pyrolysis By-Products. 10. Resins with Carboxyl Groups Based on $\mathrm{C}_{9}$ Fraction from Gasoline Pyrolysis. Ecol. Chem. Eng. S 2006, 13 (12), 1345-1352.

[16] Bratychak, M.; Romashko, I., Shyshchak, O.; Bratychak, Mich.; Waclawek, W. Obtaining of Petroleum Resins Using Pyrolysis By-Products. 11. Resins with Carboxyl Groups Synthesized in the Presence Peroxydiglutaric Acid. Ecol. Chem. Eng. S 2007, 14 (S2), 245-252.

[17] Bratychak, M.; Romashko, I., Shyshchak, O.; Waclawek, W. Obtaining of Petroleum Resins Using Pyrolysis By-Products. 7. Resins with Carboxy Groups and Block-Cooligomers Based on Them and Polyethylene Glycol. Ecol. Chem. Eng. S 2006, 13 (S1), 7-16.

[18] Grynyshyn, O.; Bratychak, M.; Krynytskiy, V.; Donchak, V. Petroleum Resins for Bitumens Modification. Chem. Chem. Technol. 2008, 2, 47-53. https://doi.org/10.23939/chcht02.01.047 [19] Bratychak, M.; Grynyshyn, O.; Astakhova, O.; Shyshchak, O.; Waclawek, W. Obtaining of Petroleum Resins Using Pyrolysis ByProducts. 13. Petroleum Resins with Hydroxyl Groups Modified with Styrene. Ecol. Chem. Eng. S 2008, 15 (3), 387-396.

[20] Bratychak, M.; Ripak, O.; Namiesnik, J.; Shyshchak, O.; Astakhova, O. Obtaining of Coumarone-Indene Resins Based on Light Fraction of Coal Tar. 2. Coumarone-Indene Resins with 
Epoxy Groups. Chem. Chem. Technol. 2018, 12, 93-100.

https://doi.org/10.23939/chcht12.01.093

[21] Sidun, I.; Solodkyy, S.; Shved, M.; Astakhova, O.; Shyshchak, O.; Bratychak, M. Obtaining of Coumarone-Indene Resins Based on Light Fraction of Coal Tar. 5. Emulsions on the Basis of Bitumen Modified by Coumarone-Indene Resins with Epoxy Groups. Chem. Chem. Technol. 2019, 13, 489-494.

https://doi.org/10.23939/chcht13.04.489

[22] Bratychak, M.; Astakhova, O.; Prysiazhnyi, Y.; Shved, M.;

Shyshchak, O.; Namiesnik, J.; Plonska-Brzezinska, M. Obtaining of Coumarone-Indene Resins Based on Light Fraction of Coal Tar. 3. Coumarone-Indene Resins with Methacrylic Fragments. Chem.

Chem. Technol. 2018, 12, 379-385.

https://doi.org/10.23939/chcht12.03.379

[23] Kutova, J. Problemy Utylizacii Vidhodiv.

https://sites.google.com/site/smittausvititaukraieni/home/ (accessed May 12, 2021)

[24] Bradford, A. Pollution Facts \& Types of Pollution. https://www.livescience.com/22728-pollution-facts.html (accessed May 12, 2021)

[25] Horner, J.M. Environmental Health Implications of Heavy Metals Pollution from Car Tyres. Environ. Health Rev. 1999, 11 (4), 175-178. https://doi.org/10.1515/REVEH.1996.11.4.175

[26] Coleman, L.W. Tire Recycling and the Environment: Benefits and Challenges. EHS Daily Advisor, Mar 22, 2021.

https:/ehsdailyadvisor.blr.com/2021/03/tire-recycling-and-theenvironment-benefits-and-challenges/

[27] Wulandari, P.S.; Tjandra, D. Use of Crumb Rubber as an Additive in Asphalt Concrete Mixture. Procedia Eng. 2017, 171, 1384-1389. https://doi.org/10.1016/j.proeng.2017.01.451

[28] Lushinga, N.; Cao, L.; Dong, Z.; Yang, C.; Assogba, C.O. Performance Evaluation of Crumb Rubber Asphalt Modified with Silicone-Based Warm Mix Additives. Adv. Cicil Eng. 2020, 2020, Article ID 4840825. https://doi.org/10.1155/2020/4840825 [29] Nagurskyy, A.; Khlibyshyn, Y.; Grynyshyn, O. Bitumen Compositions for Cold Applied Roofing Products. Chem. Chem. Technol. 2017, 11, 226-229.

https://doi.org/10.23939/chcht11.02.226

[30] Grynyshyn, O.B.; Khlibyshyn, J.Y.; Nagyrskyy, A.O.; Nagurskyy, O.A. Metody Oderzannja Bitumiv iz Zalyshkiv Pererobky Vazkyh Naft. Technologicheskyy Audit i Rezervy Proizvodstva 2015, 25 (5/4), 45-48.
[31] Nkosi, N.; Muzenda, E.; Gorimbo, J.; Belaid, M. Developments in Waste Tyre Thermochemical Conversion Processes: Gasification, Pyrolysis and Liquefaction. RSC Adv. 2021, 11, 11844-11871. https://doi.org/10.1039/D0RA08966D

[32] Czajczyńska, D.; Anguilano, L.; Ghazal, H.; Krzyżyńska, R.; Reynolds, A.J.; Spencer, N.; Jouhara, H. Potential of Pyrolysis Processes in the Waste Management Sector. Therm. Sci. Eng. Prog. 2017, 3, 171-197. https://doi.org/10.1016/j.tsep.2017.06.003 [33] Ryzhkov, S.; Rudyuk, N.; Markina, L. Research of Thermal Conductivity of the Condensed Mass of the Whole Waste Tires and Determination of Their Optimum Arrangement in the Pyrolysis Reactor. East.-Eur. J. Enterp. Technol. 2016, 82 (4/5), 12-18. https://doi.org/10.15587/1729-4061.2016.73557

[34] Topilnytskyy, P.; Grynyshyn, O.; Machynskyy, O. Tekhnologia Pervynnoi Pererobky Nafty $i$ Gazu. Vydavnytsvo Lvivskoyi politekhniky: Lviv, 2014.

[35] Rybak, B.M. Analiz Nefti i Nefteprodyktov. Gostoptehizdat: Moskwa 1962.

[36] Speight, J.G. Handbook of Petroleum Product Analysis, $2^{\text {nd }}$ edn.; John Wiley \& Sons, Inc., 2015.

https://doi.org/10.1002/9781118986370

Received: June 15, 2021 / Revised: July 28, 2021 / Accepted: September 01, 2021

\section{ДОСЛІДЖЕННЯ СКЛАДУ ТА ВЛАСТИВОСТЕЙ ПІРОКОНДЕНСАТУ ПІРОЛІЗУ ЗНОШЕНИХ АВТОМОБІЛЬНИХ ШИН}

\begin{abstract}
Анотація. Одним з варіантів утилізації зномених автомобільних иин є низькотемпературний піроліз, цільовим продуктом якого є піроконденсат. Вивчено фракційний склад $i$ властивості піроконденсату піролізу гумових відходів, отриманого на промисловій установці. Проведено розділення піроконденсату на бензинову та дизельну фракиію $i$ залишок. Встановлено склад та властивості ичих фракиій. Проведено рентгенофлуоресиентний аналіз та ІЧ-спектроскопічні дослідження піроконденсату і вузьких фракиій, виділених з нього.
\end{abstract}

Ключові слова: зношені автомобільні шини, утилізація, піроліз, піроконденсат, рентгенофлуоресиентний аналіз, IЧспектроскопія. 